Reprod. Nutr. Dévelop., 1983, 23 (5), 857-873.

\title{
A descriptive study of rumen digestion in meroxenic lambs according to the nature and complexity of the microflora.
}

\author{
G. FONTY (1) (3), J.-P. JOUANY (2), P. THIVEND (2), Ph. GOUET (1), \\ J. SENAUD (3) \\ (1) Laboratoire de Microbiologie, I.N.R.A. \\ (2) Laboratoire de la Digestion, I.N.R.A. \\ Theix, 63122 Ceyrat, France. \\ (3) Laboratoire associé au C.N.R.S. $n^{\circ}$ 138, Biologie \\ comparée des Protistes, Université de Clermont II, \\ B. P. 145,63170 Aubière, France.
}

Summary. We studied in meroxenic lambs, i.e. in lambs with a simplified digestive microflora, the effect of the microflora on the quantities of solid feed intake and on the main digestive parameters in the rumen.

Axenic lambs were inoculated with a more or less complex flora, obtained by diluting $\left(10^{-6}, 10^{-7}, 10^{-8}\right)$ a pool of rumen fluid taken either from young conventional lambs before weaning from adult sheep (Pool A) or from meroxenic lambs (Pool B). A few of these lambs then were inoculated with a genus of protozoa (Endodinium sp. or Polyplastron multivesiculatum!

The results show that the main digestive parameters depended on the nature of the inocula which the lambs had received. Food consumption and volatile fatty acid concentration of the rumen fluid, low in lambs inoculated with the $10^{-8}$ dilution, were higher in lambs inoculated with a more complex microflora $\left(10^{-6}\right.$ and $10^{-7}$ dilutions). The VFA concentration measured in these lambs however was approximately two times lower than that observed in conventional animals at the same age and fed the same feed. Food intake and the development of the fermentation pattern were favoured by an early inoculation of the animals.

The complexity of the microflora appears to have influenced the composition of the VFA mixture. The latter was found to consist mainly of acetic acid in lambs inoculated with the $10^{-8}$ dilution. In lambs which received the $10^{-6}$ dilution, the composition of the VFA mixture was similar to that observed in conventional lambs.

In all animals, except in lambs $10^{-8}$, the ammonia nitrogen concentration of the rumen fluid was found to be higher during the first month after birth (between 100 and $200 \mathrm{mg} / \mathrm{ll}$. A subsequent decrease in ammonia nitrogen concentration was observed at two and a half months of age $(20$ to $40 \mathrm{mg} / \mathrm{l})$.

The establishment of protozoa ciliates in the rumen of these lambs was followed by an increase in butyric acid and ammonia nitrogen concentration.

\section{Introduction.}

In conventional animals a study of the specific role of microorganisms as well as of their interactions is difficult to achieve, given the complexity of the microbial ecosystem of the rumen. To understand the digestive mechanisms 
involved in the rumen, the microbial conponents need to be simplified by using animals with a reduced number of bacterial and protozoal species.

The gnotobiotic conditions used to study the relationship between host and digestive microflora in monogastrics can also provide an interesting approach to the study of host-microflora-microfauna interactions in ruminants. Up until now, studies involving gnotobiotic ruminants have remained limited in scope. In the main works (Mann and Stewart, 1974 ; Lysons et al., 1971, 1976 a et b ; Cheng and Wallace, 1979 ; Barr et al., 1980 ; Hobson et al., 1981), lambs were inoculated with a number of bacterial species varying from five to eleven according to the animals. With these lambs, the functions for which the bacteria were chosen could be verified and some aspects of the role of rumen bacteria in physical development could be shown. These studies demonstrated the extreme difficulty in successfully establishing cellulolytic bacteria in the rumen of gnotobiotic animals, and good growth in gnotobiotic lambs on a fibrous diet has not been obtained (Mann and Stewart, 1974). More success has been achieved in rearing lambs and reproducing rumen function when starchy feeds are used (Hobson et al., 1981). Difficulties in establishing cellulolytic bacteria were also reported by Males (1973) who failed to established Bacteroïdes succinogenes in sheep raised in isolation from birth. This is why we used " meroxenic lambs", i.e. axenic lambs inoculated with a fraction of the rumen microflora of conventional animals, to study the ecological factors determining the establishment of cellulolytic bacteria and protozoa in the rumen. This fraction of the microflora which was inoculated, although not completely known, was obtained by simplifying the microflora of conventional animals by successive dilutions (Fonty et al., 1983). The long-term aim is to determine the minimal flora that must be present in the rumen to allow cellulolytic bacteria and ciliate protozoa to be established. The kinetics of the establishment of cellulolytic bacteria ( $B$. succinogenes) and of two genera of protozoa (Entodinium and Polyplastron) in the rumen of these meroxenic lambs has been described in a previous study (Fonty et al., 1983). The aim of the present paper was to evaluate the effect of flora complexity on changes in the main parameters of digestion in the rumen of these meroxenic lambs. The results are compared with those obtained on conventionally-reared lambs.

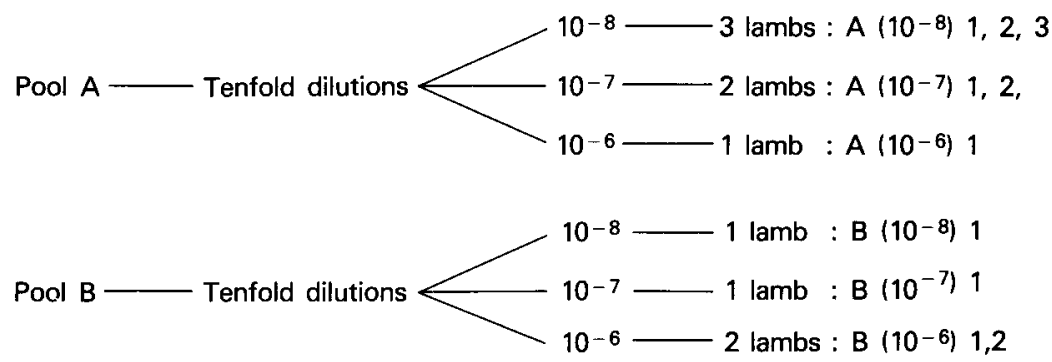

FIG. 1. - Origin and composition of inocula used for axenic lambs. Pool A was prepared from rumen contents of two conventional lambs (at age 4, 7, 9, 11, 15, 16, 18 and 21d) and from four adult sheep. Pool B was prepared from rumen contents of two meroxenic lambs lat age 60, 72 and $80 \mathrm{~d}$ ) that had previously received the $10^{-7}$ dilution of Pool $\mathrm{A}$. 


\section{Material and methods}

1. Meroxenic lambs. - The techniques for obtaining and raising the animals used have been described previously (Fonty et al., 1983). The origin and composition of the inocula used is shown in figure 1 and the time of the inoculation (with complex flora, Bacteroïdes succinogenes culture, Entodinium $s p$. culture, and Polyplastron multivesiculatum culture) in figure 2.

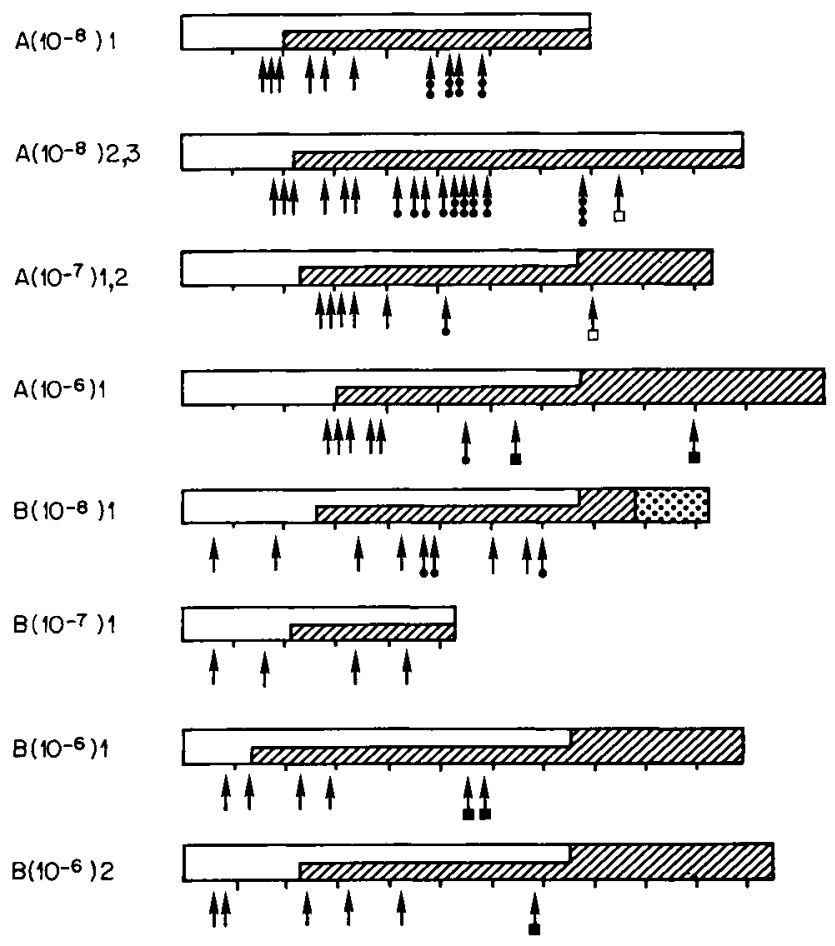

FIG. 2. - Rearing and inoculation of lambs. Feeding regime is described in Methods : milk $(\square)$;

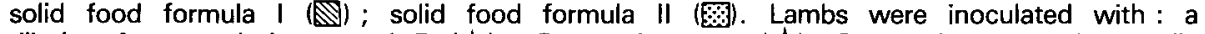
dilution from pool $A$ or pool $B(1) ; B$. succinogenes $(1), B$. succinogenes plus sterile rumen fluid $(\|) ; B$. succinogenes plus sterile rumen fluid plus cellulose powder (I); Entodinium sp. (f) or P. multivesiculatum ( $)$.

From birth to three weeks of age, the lambs received sterilized cow's milk (UHT) exclusively, then, simultaneously, milk and a solid feed sterilized by $\gamma$ irradiation (4,5 Mrads) until eleven weeks of age. During this time, the amount of milk offered decreased regularly as solid feed intake was increased. At eleven weeks of age, lambs were fed on solid food only except for lambs $A\left(10^{-8}\right)$ which had a reduced intake level and consequently continued receiving milk. The solid feed used was ground and pelleted and given twice daily. The composition 
of this feed is given in table 1. One lamb $8\left(10^{-8}\right)$ was given a second feed of dehydrated alfalfa hay at the end of the experiment.

\section{TABLE 1}

Diet composition ; Mineral and vitamins supplement

\begin{tabular}{|c|c|c|c|c|c|c|c|}
\hline \multicolumn{2}{|c|}{ Diet components (\%) } & $\begin{array}{l}\text { Minurals } \\
\text { (added) }\end{array}$ & \multicolumn{5}{|c|}{ Vitamins (added) } \\
\hline Meadow hay & 28 & $\mathrm{CoSO}_{4}, 7 \mathrm{H}_{2} \mathrm{O}$ & $31 \mathrm{mg} / \mathrm{kg}$ & Vit. A & $=$ & 12,000 & U.I. $/ \mathrm{kg}$ \\
\hline Dehydrated alfalfa & 5 & $\mathrm{FeSO}_{4}, 7 \mathrm{H}_{2} \mathrm{O}$ & $66 \mathrm{mg} / \mathrm{kg}$ & $\mathrm{D}_{3}$ & $=$ & 2,000 & \\
\hline Barley & 15 & $\mathrm{MnSO}_{4}, \mathrm{H}_{2} \mathrm{O}$ & $20 \mathrm{mg} / \mathrm{kg}$ & $E^{3}$ & $=$ & 37.5 & $\mathrm{mg} / \mathrm{kg}$ \\
\hline Oats & 4 & $\mathrm{ZnO}$ & $20 \mathrm{mg} / \mathrm{kg}$ & K & $=$ & 22.0 & $\mathrm{mg} / \mathrm{kg}$ \\
\hline Dried beet pulp & 20 & IK & $2 \mathrm{mg} / \mathrm{kg}$ & C & $=$ & 3,300 & $\mathrm{mg} / \mathrm{kg}$ \\
\hline Peanut cake & 24 & & & Thiamin & $=$ & 13 & $\mathrm{mg} / \mathrm{kg}$ \\
\hline Glucose & 3 & & & Riboflavin & $=$ & 13.7 & $\mathrm{mg} / \mathrm{kg}$ \\
\hline \multirow[t]{4}{*}{ Molasses } & 1 & & & Niacin & $=$ & 101 & $\mathrm{mg} / \mathrm{kg}$ \\
\hline & & & & Panthotenic acid & $=$ & 39.5 & $\mathrm{mg} / \mathrm{kg}$ \\
\hline & 100 & & & Choline & $=$ & 2,920 & $\mathrm{mg} / \mathrm{kg}$ \\
\hline & & & & Histine & $=$ & 1.4 & $\mathrm{mg} / \mathrm{kg}$ \\
\hline \multirow{2}{*}{\multicolumn{2}{|c|}{$\begin{array}{c}\text { Chemical corrnposition } \\
\text { of diet }(\%)\end{array}$}} & & & Folic acid & $=$ & 1.3 & $\mathrm{mg} / \mathrm{kg}$ \\
\hline & & & & Pyridoxine & $=$ & 11.7 & $\mathrm{mg} / \mathrm{kg}$ \\
\hline Organic matter & 92.8 & & & Inositol & $=$ & 0.5 & $\mathrm{mg} / \mathrm{kg}$ \\
\hline Crude fiber & 18.7 & & & Vit. $B_{12}$ & $=$ & 0.04 & $\mathrm{mg} / \mathrm{kg}$ \\
\hline Starch & 17.7 & & & & & & \\
\hline Nitrogen $(N \times 6,25)$ & 13.1 & & & & & & \\
\hline
\end{tabular}

Between the second and third weeks of age, the lambs were fitted with a permanent rumen cannula by which digesta was sampled before the morning meal (TO) and two hours after (T2), except during the period preceding weaning. During the latter period, feed intake was intermittent and consequently samples was taken only at TO. From these samples, measurements were made of $\mathrm{pH}$, volatile fatty acids (concentration and composition percentage), ammonia nitrogen concentration and lactic acid concentration.

2. Conventional lambs. - Six control lambs, reared with their dams (two lambs/dam) in conventional conditions, were weaned at six weeks of age. From the second week, they were fed the same solid feed as meroxenic lambs. One lamb was eliminated at two months because it had kidney lithiasis. Three lambs remained in the experiment until they were 95 days oid, and two until they were 120 days old.

Rumen samples were taken either through a stomach tube (in 2 lambs) or through a permanent rumen cannula (in 4 lambs). Sampling was done before the morning feeding (To) and two hours thereafter (T2). At To, rumen samples were taken only from two lambs.

3. Analysis. - Volatile fatty acids were determined by the method of Jouany (1982), ammonia nitrogen $\left(\mathrm{NH}_{3} \mathrm{~N}\right)$ by the method of Weatherburn (1967) modified by Michel (1971) and lactic acid by the Boehringer method ( 1 ).

(1) Boehringer, 2, avenue du Vercors, 38240 Meylan. 


\section{Results.}

\section{Lambs inoculated with Pool A}

1) Lamb $A\left(10^{-6}\right)$. - The food intake of this lamb was irregular (fig. 3). Solid food intake increased up to ten weeks of age. Appetite declined over the following three weeks, after which there was a gradual increase. Until three months of age, the animal consumed its ration intermittently and not as a true meal. This made it difficult to carry out a postprandial kinetic digestion study.

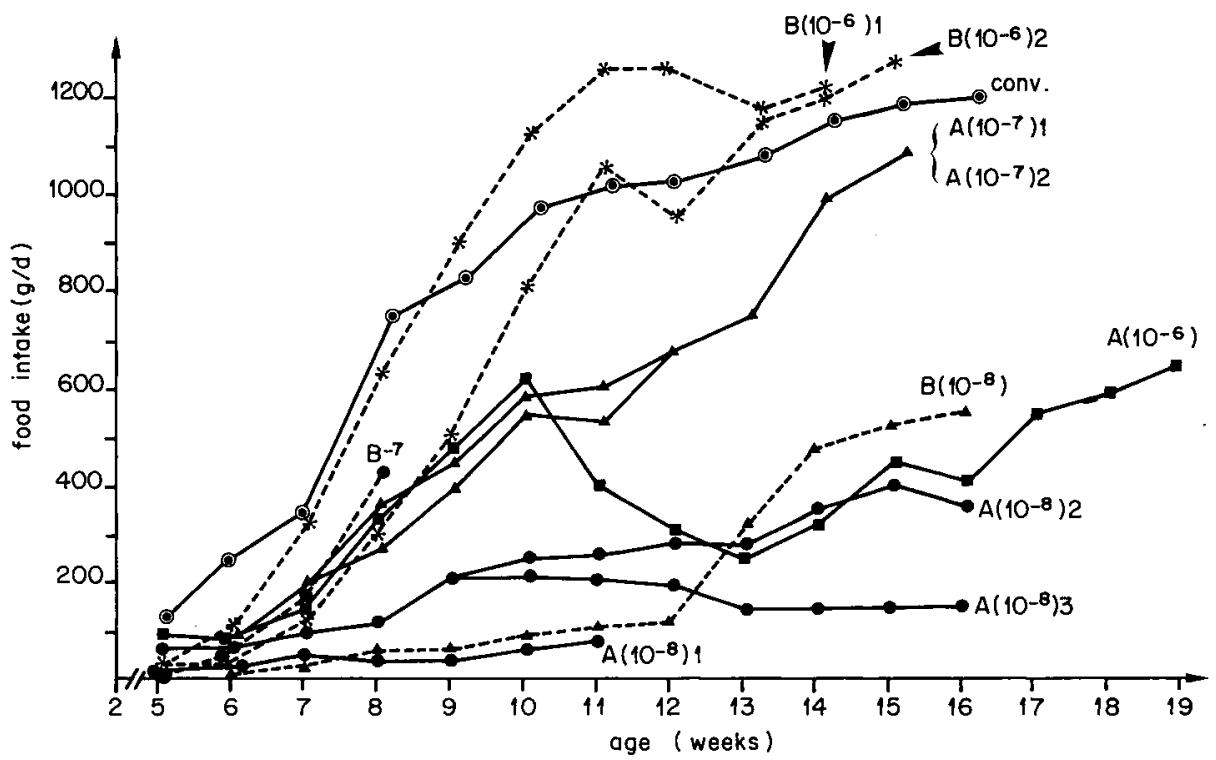

FIG. 3. - Solid food intake by meroxenic and conventional lambs. Between the third and fifth week food consumption was negligeable $(<100 \mathrm{~g} / \mathrm{d})$ and is not included in the figure.

Abnormalities in the feeding pattern and appetite probably explain the variations observed in the different digestion parameters measured (fig. 4). $\mathrm{pH}$. values varied from 5.7 to 7.0 , VFA concentration from 10 to $100 \mathrm{mM} / \mathrm{l}$ and ammonia nitrogen from 15 to $220 \mathrm{mg} / \mathrm{l}$. Lactic acid concentration ranged from 0 to $6 \mathrm{mM} / \mathrm{l}$ and 0 to $22 \mathrm{mM} / /$ for the $D$ and $L$ forms, respectively. The percentage composition of the different VFA (acetic acid : 55 to $65 \%$, propionic acid : 20 to $40 \%$, butyric acid : 10 to $20 \%$, other acids : 1 to $3 \%$ ) did not differ from those of animals with conventional flora.

Establishment of Bacteroildes succinogenes (60th day) does not seem to have modified the nature and the concentration of digestion end products, but variations in the amounts consumed could have masked the effect of this bacterium. 
2) Lambs $A\left(10^{-7}\right)$. - The consumption of solid food was satisfactory in both lambs (fig. 3). It increased regularly during the experimental period and attained values close to those found in conventional lambs.
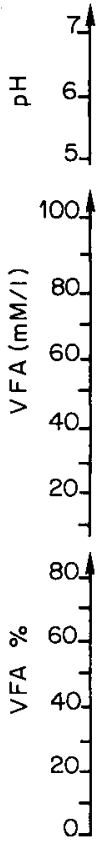
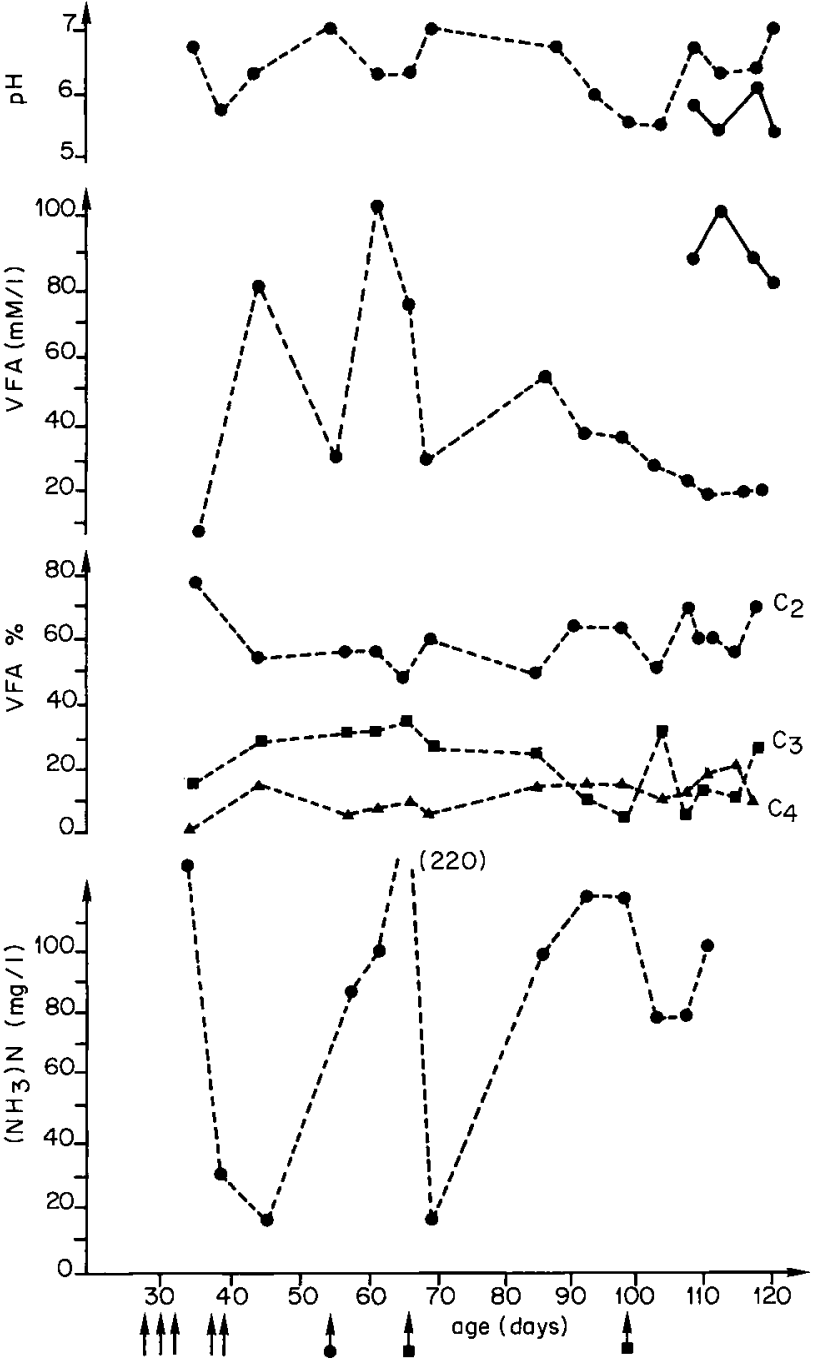

FIG. 4. - Changes in $\mathrm{pH}$; concentration and centesimal composition of VFA; ammonia nitrogen concentration in the rumen of lamb $A\left(10^{-6}\right)$. Dashed lines : values before feeding $\left(T_{0}\right)$; solid lines : values two hours after feeding $\left(T_{2}\right)$. The molar composition of VFA is that measured before feeding $\left(T_{0}\right)$. Inoculations were made with material from pool $A(f)$, with $B$. succinogenes $(\downarrow)$ and with $P$. multivesiculatum ( $\downarrow$ ) as described in figure 2 .

Compared to previous results, a more regular digestion pattern was noted in the rumen. The $\mathrm{pH}$ values remained more or less constant $\left(7\right.$ at $\mathrm{T}_{0}$ and 6 at $\left.\mathrm{T}_{2}\right)$ with little variation in total acidity (fig. 5). The latter increased naturally two 
hours after food consumption (from 50 to $90 \mathrm{mM} / \mathrm{I}$ ) and reached a maximum ten days after the introduction of Entodinium $s p$. VFA composition varied markedly from that observed in lamb $A\left(10^{-6}\right\}$, i.e. acetic acid percentage was lower; however there was a notable increase in propionic acid percentage. The introduction of Entodinium sp. brought about an increase in $\mathrm{C}_{2}$ and $\mathrm{C}_{4}$ concentrations; however, there was a marked decrease in the percentage of propionic acid.
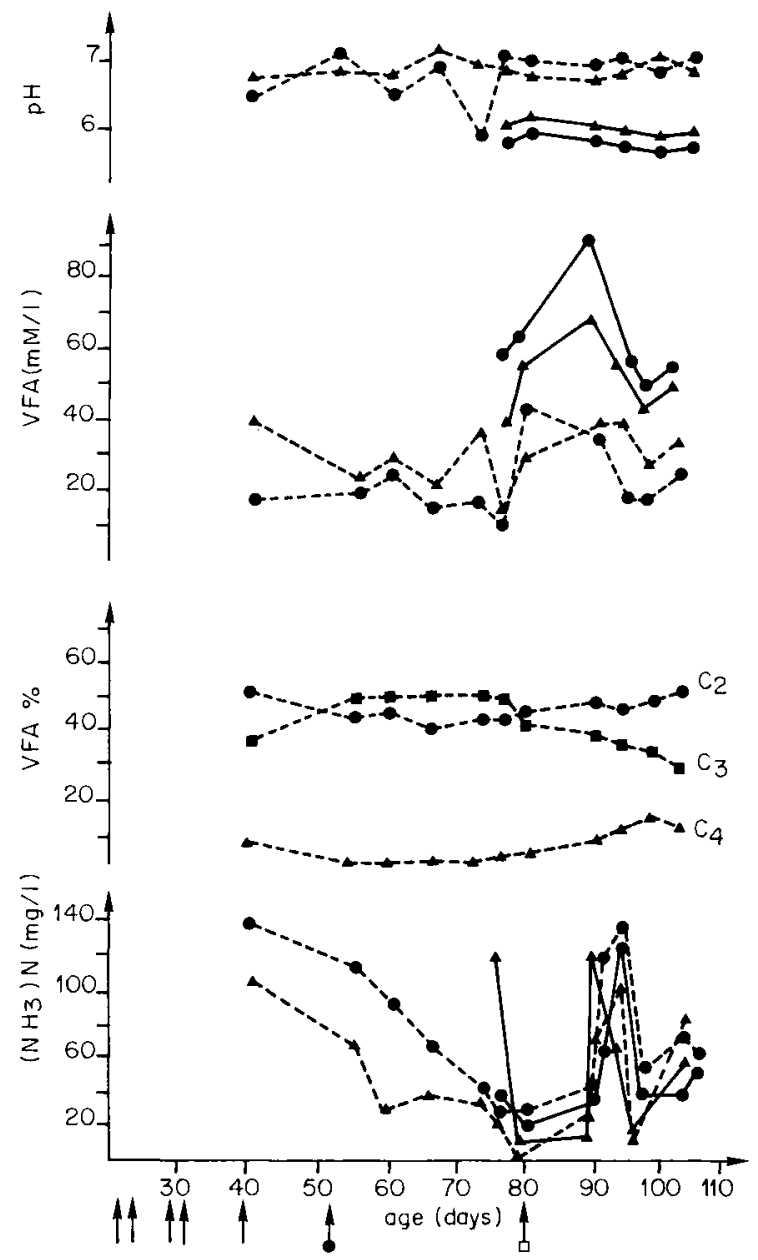

FIG. 5. - Changes in $\mathrm{pH}$; concentration and centesimal composition of VFA; ammonia nitrogen concentration in the rumen of lambs $\mathrm{A}\left(10^{-7}\right)_{1}(\bullet)$ and $\mathrm{A}\left(10^{-7}\right)_{2}(4)$. Dashed lines : values before feeding (To) ; solid lines : values two hours after feeding $\left(T_{2}\right)$. The molar composition of VFA is that measured in lamb $A\left(10^{-7}\right)$, before feeding (To). Inoculations were made with vilaterial from pool $A(1)$, with $B$. succinogenes $(I)$ and with Entodinium sp. $(1)$ as described in figure 2 . 
The ammonia nitrogen concentration decreased regularly for the first 60 days of measurement, then rose abruptly when Entodinium $s p$. was established. The lactic acid concentration, which was zero prior to feeding, remained very low untill protozoa establishment $\left(2\right.$ to $4 \mathrm{mM} / /$ at $\left.T_{2}\right)$; it then rose slightly $(4$ to $10 \mathrm{mM} / \mathrm{l})$. L-lactate was mainly involved.

3) Lambs $A\left(10^{-8}\right)$. - Three lambs were used. Since one of these animals (lamb $A\left(10^{-8}\right)$, refused practically all solid foods (daily consumption : $<50 \mathrm{~g}$ ),
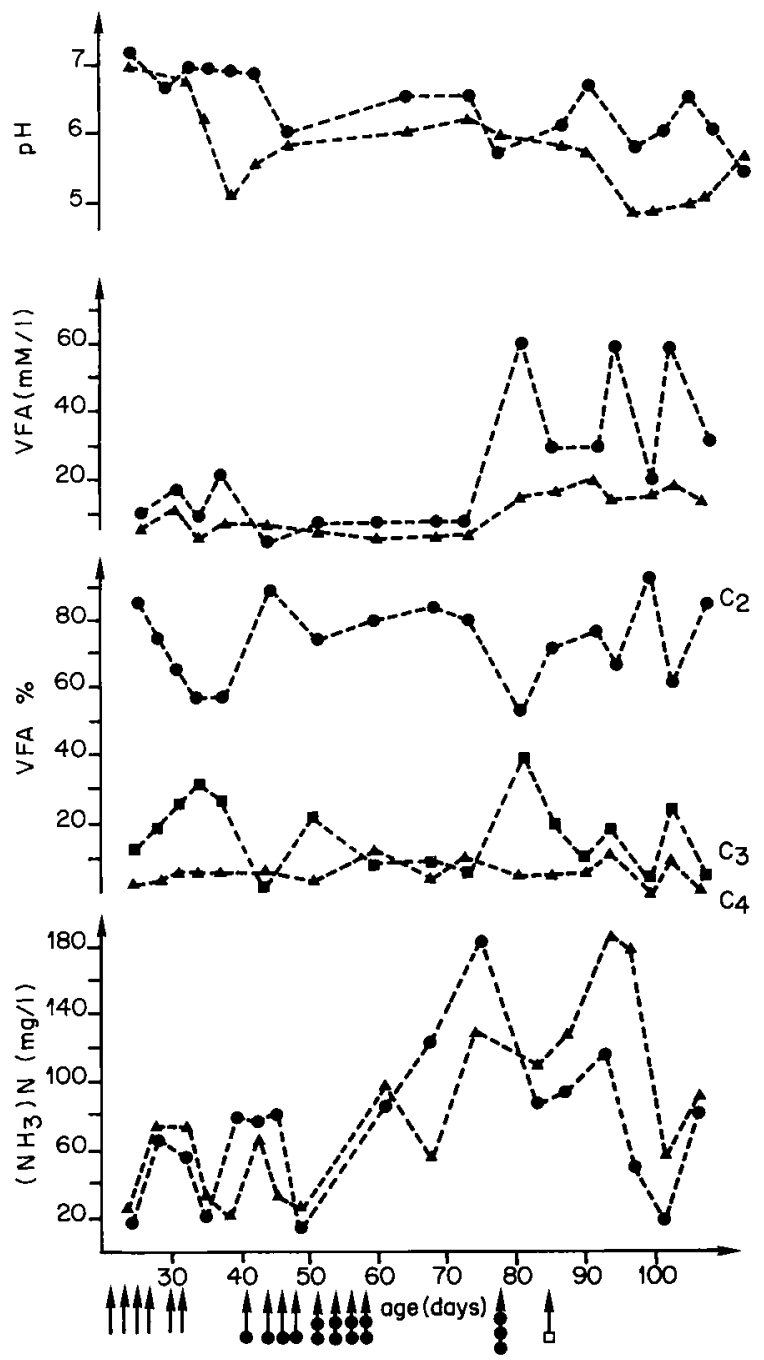

FIG. 6. - Changes in pH; concentration and centesimal composition of VFA; ammonia nitrogen concentration in the rumen of lambs $A\left(10^{-8}\right)_{2}(\bullet)$ and $A\left(10^{-8}\right)_{3}(4)$. The molar composition of VFA is that measured in lamb $A(10-8)_{2}$. Inoculations were made from material from pool $A(\uparrow)$, with $B$. succinogenes $(1)$, and with Entodinium $s p .(1)$ as described in figure 2. 
it was eliminated. The amounts eaten by the other two lambs were small : 200 to $250 \mathrm{~g} /$ day at ten weeks of age for one lamb and approximately $400 \mathrm{~g} /$ day at fifteen weeks of age for the second lamb. As indicated for lamb $A\left(10^{-6}\right)$, feed consumption was intermittent throughout the day. This, no doubt, explains why $\mathrm{pH}$ variations were sometimes considerable, from one sampling to the next (fig. 6).

The VFA concentration was very low up to the age of ten weeks (10 to $15 \mathrm{mM} / \mathrm{l})$; however, it significantly increased in lamb $A\left(10^{-8}\right)_{2}$ after $B$. succinogenes establishment, but the amplitude of the variations was high. In the
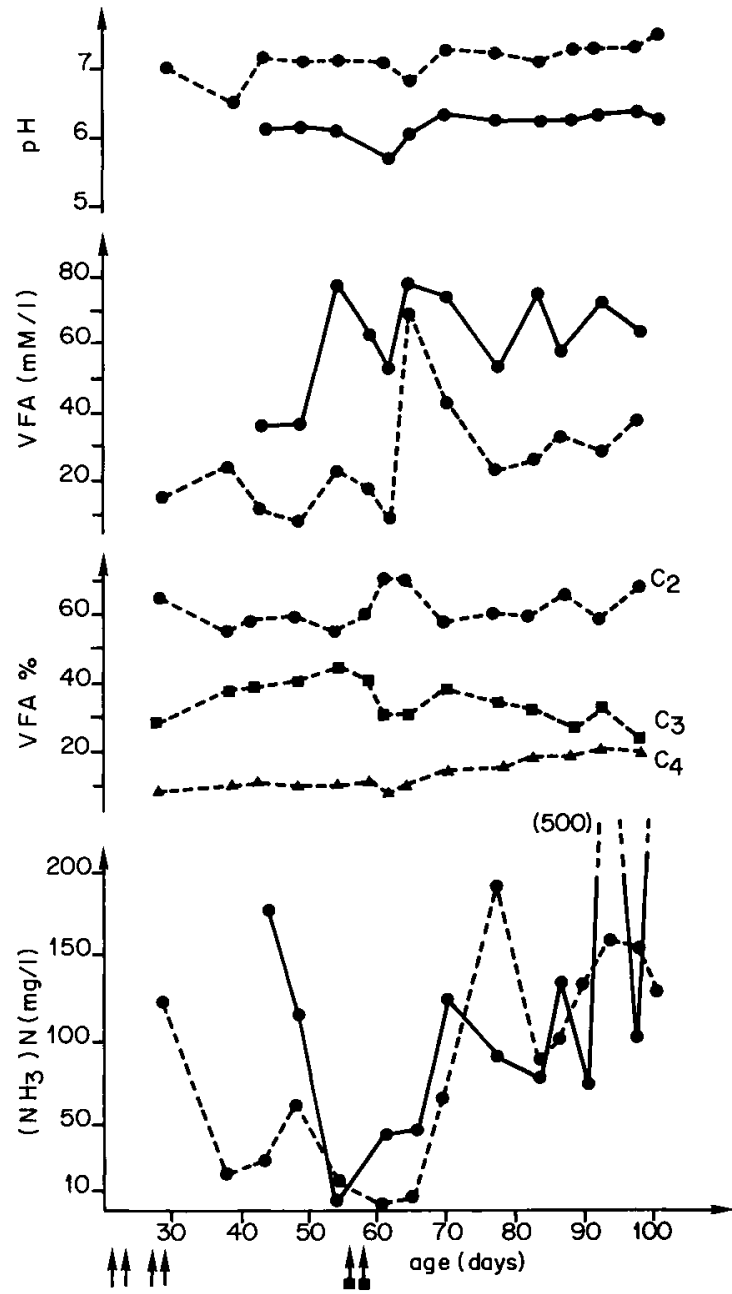

FIG. 7. - Changes in $\mathrm{pH}$; concentration and centesimal composition of VFA; ammonia nitrogen concentration in the rumen of lamb $B\left(10^{-6}\right)$. The molar composition of VFA is that measured before feeding (To). Inoculations were made with material from pool $(B(\uparrow)$ and with $P$. multivesiculatum $(1)$ as described in figure 2 . 
other animal (lamb $\mathrm{A}\left(10^{-8}\right)_{3}, B$. succinogenes was not established. The slight increase observed from the eleventh week onward was probably due to the presence of sterile rumen liquor introduced at the same time as the $B$. succinogenes strain (fig. 2).

The composition of the VFA mixture was very different from that of the lambs which received more concentrated inocula (i. e.) essentially acetic acid $(80 \%)$, propionic acid (10 to $12 \%)$ and variable but small amounts of butyric acid were detected. The other acids never accounted for more than $1 \%$ of the mixture and, in most cases, were even absent.

The ammonia nitrogen concentration of the rumen liquor was very low during the first two months (25 to $30 \mathrm{mg} / \mathrm{l})$. It then increased, but as for other parameters, there were great variations from one sampling to the next.

\section{Lambs inoculated with pool B.}

Contrary to what was done with animals from pool A (inoculated from the age of three weeks on), those from group $B$ were inoculated at an earlier age (from the first week on) in order to foster rumen development.

1) Lambs $B\left(10^{-6}\right)$. - These two animals had little appetite until the sixth week ( 50 to $100 \mathrm{~g} /$ day). Then appetite increased markedly and food intake attained $1.2 \mathrm{~kg}$ per day during the twelfth week (fig. 3 ).

At $T_{0}, \mathrm{pH}$ varied little $\left\{6.8\right.$ and 7 on the average for lambs $\mathrm{B}\left(10^{-6}\right) 1$ and $\mathrm{B}\left(10^{-6}\right) 2$, respectively. Generally, $\mathrm{pH}$ decreased by one unit after feeding. Polyplastron mutivesiculatum establishment did not modify these values (fig. 7 and 8 ).

Before protozoa establishment, VFA concentration was relatively low before the meal, especially in lamb $B\left(10^{-6}\right)_{1}$. It was twice as high two hours after feeding. Acetic acid predominated (50-60\%), with propionic acid accounting for 35 to $40 \%$. However, the percentage of butyric acid was low (5 to $6 \%$ ). The totality of the other acids accounted for approximately $2 \%$. After $P$. multivesiculatum was introduced, the VFA concentration rose in both animals, especially after feeding. The proportion of acetic and butyric acids increased while that of propionic acid decreased.

Before the introduction of $P$. multivesiculatum ammonia nitrogen concentrations decreased from $130 \mathrm{mg} / /$ to $10 \mathrm{mg} / \mathrm{l}$. With the introduction of this species, there was a significant increase in ammonia concentration both at $T_{0}$ and at $T_{2}$. However, there were great variations between samplings, especially for lamb $\mathrm{B}\left(10^{-6}\right)_{1}$. Moreover, the differences between concentrations measured before and after the meal were small. Lactic acid concentration, which was very low, increased after the establishment of $P$. multivesiculatum (5 to $10 \mathrm{mM} / \mathrm{l}$ ). The $D$ and $L$ isomers were in equal proportions.

2) Lamb $B\left(10^{-7}\right)$. - This animal was withdrawn from the experiment at 52 days of age after an accident occurred inside the isolator.

During the measurement period, feed consumption and $\mathrm{pH}$ values before and 2 hours after feeding were very close to those noted in lambs $B\left(10^{-6}\right)$. The 

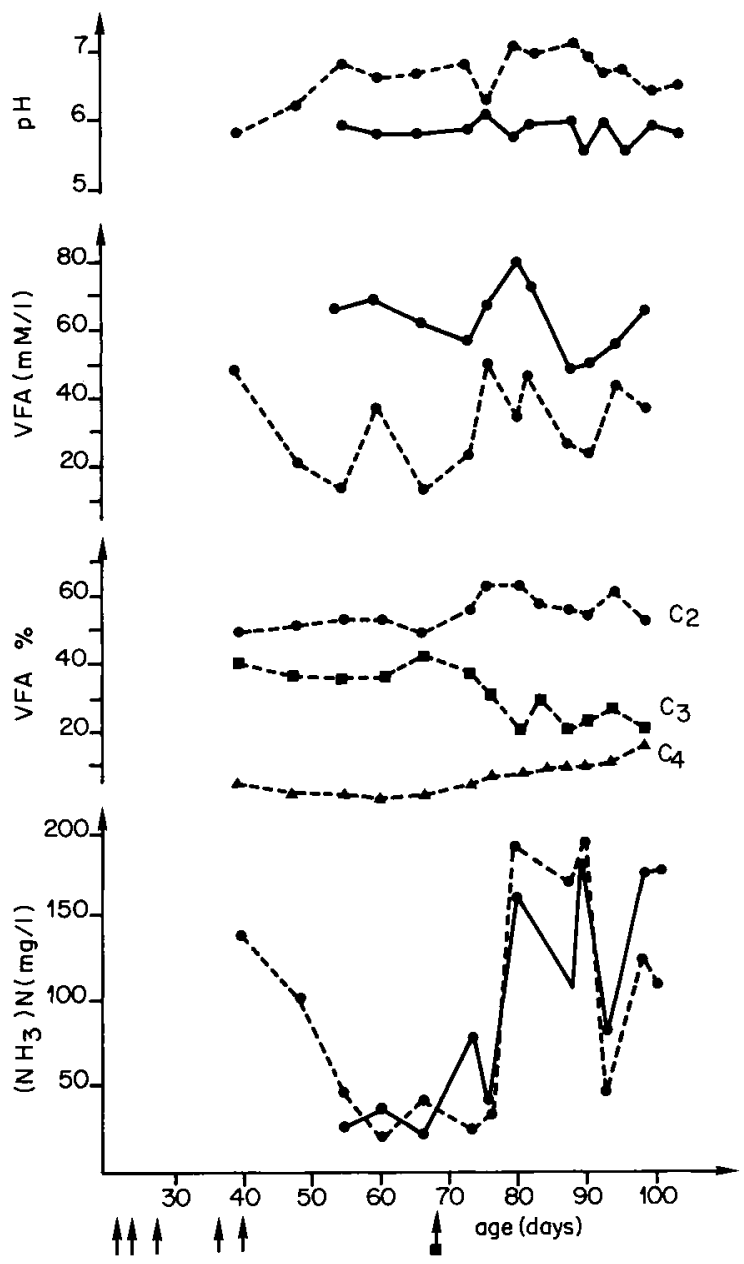

FIG. 8. - Changes in $\mathrm{pH}$; concentration and centesimal composition of VFA; ammonia nitrogen concentration in the rumen of lamb $B\left(10^{-6)}\right.$. The molar composition of VFA is that measured before feeding (To). Inoculations were made with material from pool B (1), and with P. multivesiculatum $(\{)$ as described in figure 2 .

VFA concentration was between 20 and $40 \mathrm{mM} / /$ inclusively at $T_{0}$, and between 40 to $80 \%$ at $\mathrm{T}_{2}$. Acetic acid accounted for 30 to $52 \%$, propionic acid 40 to $45 \%$, and butyric 6 to $7 \%$ of the VFA mixture. The ammonia nitrogen concentration was low (20 to $40 \mathrm{mg} / \mathrm{l})$.

3) Lambs $B\left(10^{-8}\right)$. - Until the ninth week, solid feed intake was almost zero, $\mathrm{pH}$ remained acidic (5.8), the ammonia nitrogen was low $(30 \mathrm{mg} / \mathrm{l})$ and VFA concentration negligible. At this time, the animal received a dilution of $7.5 \times 10^{-8}$ from the same pool (fig. 2) and 5 days later a Bacteroïdes succinogenes culture. 
The introduction of this more complex flora had an effect on all the parameters measured. Appetite increased, $\mathrm{pH}$ levelled off at 7.3 on the average before feeding and at 6.3 two hours after. The VFA concentration attained values between 30 and $70 \mathrm{mM} / \mathrm{l}$ (fig. 9). The centesimal composition of the VFA was also modified. When the animal hosted a simple flora, acetic acid proportion attained values of 80 to $90 \%$. With the introduction of the more complex flora, propionic and butyric acids proportions increased with a consequent decrease in the proportion of acetic acid. The change in the feed after the 85th day modified nothing in this composition.
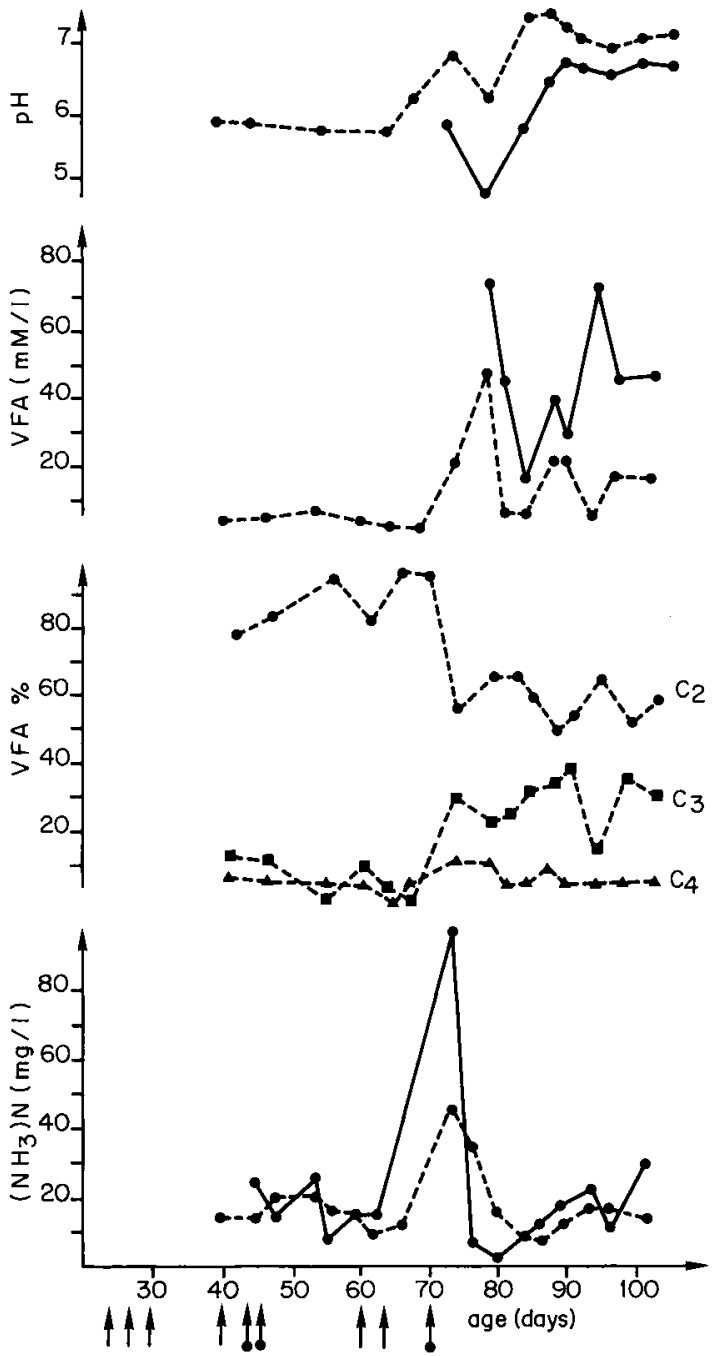

FIG. 9. - Changes in $\mathrm{pH}$; concentration and centesimal composition of VFA; ammonia nitrogen concentration in the rumen of lamb $B\left(10^{-8}\right)$. The molar composition of VFA is that measured before feeding (To). Inoculations were made with material from pool B (1), and with $B$. succinogenes $(\ell)$ as described in figure 2 . 
The ammonia nitrogen concentration was also increased after the $7.5 \times$ $10^{-8}$ dilution was introduced $(95 \mathrm{mM} / \mathrm{l})$, but this then decreased and levelled off at values close to those previously observed $(25 \mathrm{mg} / \mathrm{l})$. The lactic acid concentration was high during the first two months $(25$ to $35 \mathrm{mM} / \mathrm{l})$ both prior to and two hours after feeding. This large amount of acid ( $L$ form) was due to the predominance of streptococci in the rumen flora (Fonty et al., 1983). After inoculating the $7.5 \times 10^{-8}$ dilution, the concentration dropped considerably $1<2 \mathrm{mM} / \mathrm{l})$.
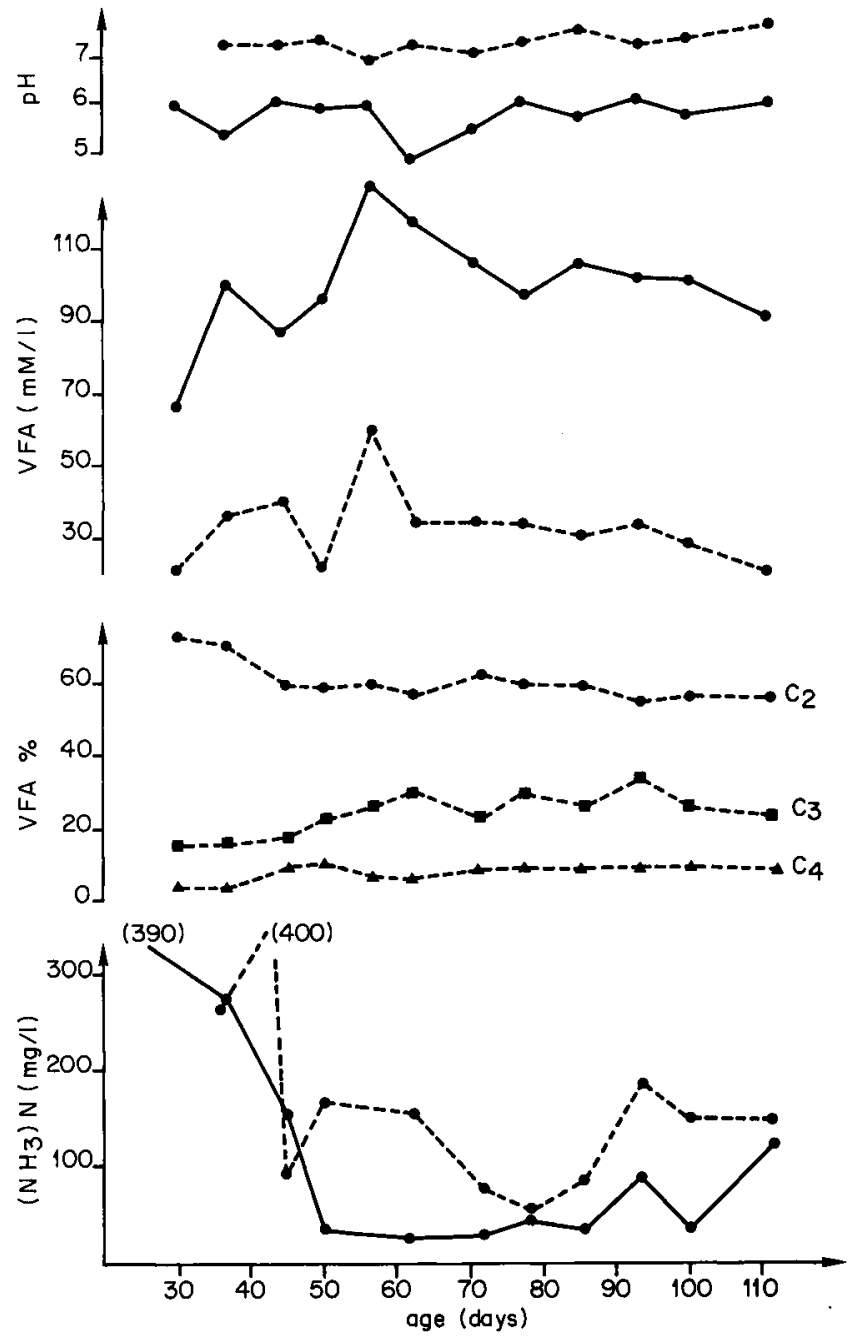

FIG. 10. - Changes in $\mathrm{pH}$; concentration and centesimal composition of VFA; ammonia nitrogen concentration in the rumen of conventional lambs. The molar composition of VFA is that measured before feeding (To). Each value is the mean of two lambs at To and of six lambs at $T_{2}$. 


\section{Conventional lambs.}

The food intake (fig. 3) of these lambs, which was about 100 to $150 \mathrm{~g}$ per day until fifth week, increased rapidly after weaning and reached $1 \mathrm{~kg} /$ day the ninth week, and $1.2 \mathrm{~kg}$ at 4 months.

Until the lambs were 40 days old, their VFA concentration (fig. 10) was low and variable, depending on the lambs. Then, it increased regularly and reached about $100 \mathrm{mM} / \mathrm{I}$ two hours after feeding at the age of 60 days. The percentages of the VFA mixture were the following : acetic acid $(60-62 \%$ ), propionic acid (23 to $28 \%$ ), butyric acid ( 7 to $10 \%$ ), other acids ( 3 to $5 \%$ ).

The ammonia nitrogen concentration (fig. 10) was high during the first month (250 to $400 \mathrm{mg} / 1$ ). Then it decreased markedly until the lambs were 50 days old (50 to $150 \mathrm{mg} / \mathrm{l}$ before feeding and 30 to $100 \mathrm{mg}$ two hours afterwards).

\section{Discussion.}

The amounts of solid feed consumed by the animals varied, firstly, as a function of inoculum complexity and, secondly, depending on the age when inoculation was performed. In contrast, these amounts of solid feed were not modified by the presence of ciliate protozoa. On the whole, intake was high in animals that received inocula with complex bacterial compositions $\left(10^{-6}\right.$ and $10^{-7}$ dilutions) and was low, particularly up to 2 months of age, in lambs receiving simplified inocula $\left(10^{-8}\right.$ dilutions). In other respects, solid feed intake was both more rapid and quantitatively greater in lambs inoculated from the first week on (group B) than in lambs inoculated from the third week on (group A). Early inoculation of animals soon after birth thus favours the intake of solid food and the development of the rumen. This relationship between flora complexity and feed consumption is a particularity of the ruminant. Indeed, Lukey (1965) found no differences in food intake among comparable groups of germ-free and conventional rats. In some cases, intake was greater in germ-free rats (Combe et al., 1965) or mice (Gordon, 1968), and Szylit and Charlet (1981) showed that gross energy intake was slightly higher in monoxenic and axenic chickens than in holoxenic ones.

There is also a good relationship between the development of rumen function and flora complexity. Thus, the VFA concentration, measured two hours after feeding, was much higher in animals which receved more complex inocula and consumed greater quantities of food lambs $A\left(10^{-6}\right), A\left(10^{-7}\right)$ and $\left.B\left(10^{-6}\right)\right)$. Nonetheless, the VFA concentrations were clearly lower than those measured in conventional animals of the same age receving the same feed (50 to $80 \mathrm{mM} / \mathrm{I}$ instead of 95 to $120 \mathrm{mM} / \mathrm{l}$ ).

The percentage composition of the VFA in the rumen was also greatly influenced by the type of inoculum used. For example, until week 7 acetic acid alone was present in animals which received the $10^{-8}$ dilutions of inocula $A$ and $B$ (fig. 6 and 9). The presence of propionic acid was linked to the complexity 
of the mixture of inoculated bacteria. The butyric acid content always remained low during the period prior to ciliate inoculation. It increased markedly when the animals were faunated, reaching values close to those observed in conventional animals, irrespective of the type of ciliate inoculated. This increase occured at the expense of propionic acid whatever the dilution of inoculum used. With the exception of animals $A\left(10^{-8}\right)$ and $B\left(10^{-8}\right)$, the ammonia nitrogen concentration in the rumen was high during the first month (between 100 and $200 \mathrm{mg} / \mathrm{l}$ ). At two and a half months of age there was a considerable decrease. The high initial ammonia concentration could come from the break-down of desquamated epithelial cells by bacteria that adhere to these cells (Cheng et al., 1979). Indeed, during this period, we noted that desquamation was intense and that the rumen was filled with a very thick mucous containing muco-peptides which could be hydrolysed by the proteolytic enzymes of micro-organisms present and produce ammonia. These adherent bacteria also showed an intense ureolytic activity with regard to the salivary urea and blood urea diffused throughout the rumen-wall. Ammonia absorption may also be limited in the preruminant, given the slightly acidic $\mathrm{pH}$ values of the rumen contents at that time. Lastly, as Jouany (1978) noted, the presence of ciliate protozoa brought about an increase in the ammonia concentration of the rumen. This can be explained either by the hydrolysing action of ciliates, by the decrease in the number of bacteria after ciliates are introduced (Eadie and Hobson, 1962 ; Kurihara et al., 1968, Fonty et al., 1983), or by the occurence of both simultaneously.

It would appear from our results that the presence of a simple flora cannot assure the digestive function as a complex flora can. To corroborate this, it has been shown (Fonty et al., 1983) in these same lambs inoculated with dilutions greater than $10^{-7}$, that the establishment of cellulolytic bacteria is very difficult and even impossible in some cases. That early inoculation of animals is a factor favouring fermentation and digestive activities in the rumen is probably related to the action of bacteria on papilla, rumen mucosa, and digestive tract development (Lysons et al., 1976 b).

In this study we used an approach to host microflora relationships which consisted of inoculating axenic lambs with more and more simplified fractions of flora obtained from conventional animals. Although this approach is often used in monogastrics, it has never been applied, to our knowledge, to the preruminant. But in monogastrics, this model was used to study a specific microbiological problem (Ducluzeau et al., 1977 ; Sacquet et al., 1979), not a nutritional one.

Our study confirms the difficulties encountered in the management of gnotoxenic lambs. It also demonstrates the interactions between the host and its microflora as well as interactions between the diverse bacterial species which permit the rumen to function. This is not entirely due to the presence of a dominant flora but also to a number of other species which play an important symbiotic role in the rumen and are often underestimated. 
Acknowledgements. - We wish to thank J. Lefaivre who fistulated the animals, MariePaule Girard, Paulette Journaix, Marie-Thérèse Beauford and M. Chavarot, G. Andant, G. Vert for their valuable technical assistance.

Résumé. Etude descriptive de la digestion dans le rumen d'agneaux méroxéniques selon la nature et la complexité de la microflore.

Nous avons étudié chez des agneaux méroxéniques c'est-à-dire chez des animaux dont la microflore digestive était simplifiée par rapport à celle d'animaux conventionnels, l'effet de la microflore sur les quantités d'aliments solides ingérées par les agneaux et sur l'évolution des principaux paramètres de la digestion au niveau du rumen.

Les agneaux axéniques ont été inoculés avec des flores plus ou moins complexes obtenues par dilution $\left(10^{-6}, 10^{-7}, 10^{-8}\right)$ d'un pool de jus de rumen, prélevé soit chez de jeunes agneaux conventionnels non sevrés et des moutons adultes (Pool $A$ ), soit chez des agneaux méroxéniques (Pool B). Certains animaux ont ensuite été également inoculés par un genre de protozoaire (Endodinium sp. ou Polyplastron multivesiculatum).

Les résultats ont montré que les principaux paramètres digestifs dépendent de la nature de l'inoculum qu'ont reçu les agneaux. En effet, la consommation d'aliment, la concentration en acides gras volatils du jus de rumen, très faibles chez les agneaux inoculés avec les dilutions $10^{-8}$, ont été plus importantes chez les agneaux ayant reçu des flores plus complexes (dilutions $10^{-6}$ et $10^{-7}$ ). Toutefois la concentration en AGV mesurée chez ces agneaux était environ 2 fois plus faible que celle d'animaux conventionnels de même âge et recevant le même aliment. Nous avons également noté que la consommation d'aliment solide et la mise en place des fermentations ont été favorisées par une inoculation précoce des animaux.

La composition centésimale du mélange d'AGV est en relation avec la complexité de la microflore. II est constitué principalement d'acide acétique chez les animaux inoculés avec les dilutions $10^{-8}$. Chez les agneaux ayant reçu les dilutions $10^{-6}$, ce mélange a une composition qui se rapproche de celle observée chez les conventionnels.

Exception faite des agneaux ayant reçu les inoculums $10^{-8}$, la concentration en azote ammoniacal du jus de rumen a été plus élevée pendant le premier mois (entre 100 et $200 \mathrm{mg} / \mathrm{l}$ ) puis a diminué pour atteindre des valeurs très faibles à l'âge de 2 mois et demi (40 à $50 \mathrm{mg} / \mathrm{l}$ ).

L'implantation des protozoaires ciliés dans le rumen de ces agneaux a entraîné une augmentation de la concentration en acide butyrique et de la concentration en azote ammoniacal.

\section{Références}

BARR M. E. J., MANN S. O., RICHARDSON A. J., STEWART C. S., WALLACE R. J., 1980. Establishment of ureolytic staphylococci in the rumen of gnotobiotic lambs. J. appl. Bacteriol., 49, 325-330.

CHENG K. J., Mc COWAN R. P., COSTERTON J. W., 1979. Adherent epithelial bacteria in ruminants and their roles in digestive tract function. Am. J. clin. Nutr., 32, 139-148.

CHENG K. J., WALLACE R. J., 1979. The mechanism of passage of endogenous urea through the rumen wall and the role of ureolytic bacteria in the urea flux. Br. J. Nutr., 42, 553-557.

COMBE E., PENOT E., CHARLIER H., SACQUET E., 1965. Metabolisme du rat germ-free. Teneurs des contenus digestifs en certains composés azotés, en sodium et en potassium. Teneurs de quelques tissus en acides nucléiques. Ann. Biol. anim. Bioch. Biophys., 5, 189206.

DUCLUZEAU R., RAIBAUD P., 1980. Intérêt des systéines gnotoxéniques pour l'étude des relations hôte-flore microbienne du tube digestif. Reprod. Nutr. Dévelop., 20, 1667-1678.

DUCLUZEAU R., LADIRE M., CALLUT C., RAIBAUD P., ABRAMS G. D., 1977. Antagonist effect of extremely oxigen-sensitive clostridia from the microflora of conventional mice and Escherichia Coli against Shigella flexneri in the digestive tract of gnotobiotic mice. Inf. Imm., 17, 415-424. 
EADIE J. M., HOBSON P. N., 1962. Effect of presence or absence of ciliates on the total bacteria count in lambs. Nature, London, 193, 503-505.

FONTY G., GOUET Ph., JOUANY J. P., SENAUD J., 1983. Ecological factors determining establishment of cellulolytic bacteria and protozoa in the rumens of meroxenic lambs. J. gen. Microbiol., 129, 213-223.

GORDON H. A., 1968. Is the germ free animal normal ? 127-130. In M. E. COATES, The germfree animal in research. Acad. Press. Inc, New-York.

HOBSON P. N., MANN S. O., STEWART C. S., 1981. Growth and rumen function of gnotobiotic lambs fed on starchy diets. J. gen. Microbiol., 126, 219-230.

JOUANY J. P., 1978. Contribution à l'étude des protozoaires ciliés du rumen, leur dynamique, leur rôle dans la digestion et leur intérêt pour le ruminant. Th. Doc. Etat, $\mathrm{n}^{\circ} \mathrm{d}^{\prime}$ ordre 256. Univ. Clermont II, France.

JOUANY J. P., 1982. Volatile fatty acid and alcohol determination in digestive contents, silage juices, bacterial cultures and anaerobic fermentor contents. Sciences des Aliments, 2, 131144.

KURIHARA Y., EADIE J. M., HOBSON P. N., MANN S. O., 1968. Relationships between bacteria and ciliate protozoa in the sheep rumen. J. gen. Microbiol., 51, 267-288.

LUKEY T. D., 1965. Effects of microbes on germ-free animals. Adv. appl. Microbio/., 7, $169-223$.

LYSONS R. J., ALEXANDER T. J. L., HOBSON P. N., MANN S. O., STEWART C. S., 1971. Establishment of a limited rumen microflora in gnotobiotic lambs. Res. vet. Sci., 12, 486487.

LYSONS R. J., ALEXANDER T. J. L., WELLSTEAD P. D., HOBSON P. N., MANN S. O., STEWART C. S., 1976 a. Defined bacterial population in the rumen of gnotobiotic lambs. J. gen. Microbiol., 94, 257-269.

LYSONS R. J., ALEXANDER T. J. L., WELLSTEAD P. D., JENNINGS I. W., 1976 b. Observations on the alimentary tract of gnotobiotic lambs. Res. vet. Sci, 20, 70-76.

MALES J., 1973. Ration digestibility, rumen bacteria and several rumen parameters in sheep born and reared in isolation. Diss. The Ohio State Univ.

MANN S. O., STEWART C. S., 1974. Establishment of a limited rumen flora in gnotobiotic lambs fed a roughage diet. J. gen. Microbiol., 84, 379-382.

MICHEL M., 1971. Analyse quantitative de quelques substances azotées et g/ucidiques en milieu biologique. Essai de rationalisation. Th. Univ., Clermont-Ferrand, $n^{\circ} d^{\prime o r d r e ~ 43,}$ $79 p p$.

RIOU Y., GOUET Ph., DUBOURGUIER H. C., CONTREPOIS M., DARDILLAT C., LEFAIVRE J. Technics for obtaining fistulization and rearing of axenic or gnotoxenic lambs, kids and calves. Ann. Rech. vét., 8, 13-24.

SACQUET E. C., RAIBAUD P. M., MEJEAN C., RIOTTOT M. J., LEPINCE C., LÉGLISE P. C., 1979. Bacterial formation of $\omega$-Muricholic acid in rats. Appl. Environt. Microbiol., 37, 1127-1131.

SZYLIT O., CHARLET G., 1981. Energy and protein retention in holoxenic, axenic and gnotoxenic chickens monoassociated with lactobacillus sp. Br. Poultry. Sci., 22, 305-315.

WEATHERBURN M. W., 1967. Phenol hypochlorite reaction for determining ammonia. Analyt. Chem., 39, 971-974. 